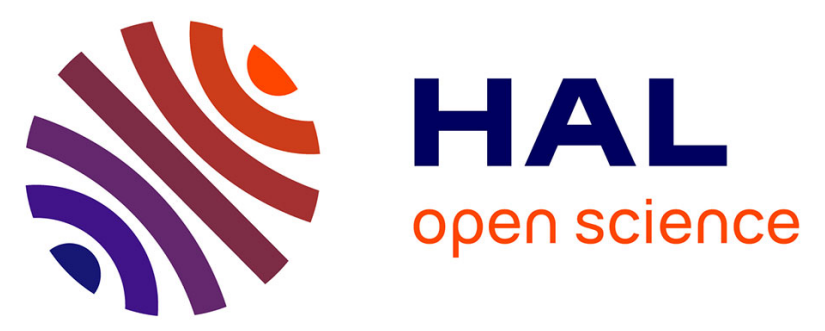

\title{
A qualitative analysis of universal basic education policy implementation strategies in Nigeria: Effective management for goals realization
}

Arop Festus Obun, Valentine Joseph Owan, Ekpang Martin Akan

\section{- To cite this version:}

Arop Festus Obun, Valentine Joseph Owan, Ekpang Martin Akan. A qualitative analysis of universal basic education policy implementation strategies in Nigeria: Effective management for goals realization. International Journal of Research and Innovation in Social Science, 2018. hal-03042592

\section{HAL Id: hal-03042592 \\ https://hal.science/hal-03042592}

Submitted on 6 Dec 2020

HAL is a multi-disciplinary open access archive for the deposit and dissemination of scientific research documents, whether they are published or not. The documents may come from teaching and research institutions in France or abroad, or from public or private research centers.
L'archive ouverte pluridisciplinaire HAL, est destinée au dépôt et à la diffusion de documents scientifiques de niveau recherche, publiés ou non, émanant des établissements d'enseignement et de recherche français ou étrangers, des laboratoires publics ou privés. 


\title{
A Qualitative Analysis of Universal Basic Education Policy Implementation Strategies in Nigeria: Effective Management for Goals Realization
}

\author{
Arop Festus Obun ${ }^{1}$, Owan Valentine Joseph ${ }^{2}$, Ekpang Martin Akan ${ }^{3}$ \\ ${ }^{1,3}$ Ph.D, Department of Educational Administration and Planning, University of Calabar, Calabar, Nigeria \\ ${ }^{2}$ Department of Educational Administration and Planning, University of Calabar, Calabar, Nigeria
}

\begin{abstract}
The study assessed qualitatively, the implementation strategies of the Universal Basic Education (UBE) Policy in Nigeria. In order to provide insights into the topic, terms were clarified accordingly. The Universal Basic Education goals were stated as contained in the policy statement of the National Policy on Education. The proposed strategies for the realization of the goals of UBE were stated and analysed accordingly. Relevant literatures were cited to provide understanding of the issues involved. A critique was carried out on the implementation of the stated strategies in order to $x$-ray the strengths and weaknesses underlying the implementation of UBE policy. It was discovered that the formulated policy of the UBE was very good including the strategies documented to attain stated objectives of the programme. It was also observed that the programme has witness some setback at its implementation phase. Based on these problems, five critical questions were asked to serve as a blueprint for judging whether the UBE programme has achieved its objectives or not. Based on these, recommendations and conclusion were made for policy implementation reform.
\end{abstract}

Keywords: Implementation Strategies, Management, Policy, Educational policy, Universal Basic Education, Realization of goals.

\section{INTRODUCTION}

$\mathrm{T}$ he importance of education cannot be over-emphasized; as nations who prioritize education progress by leaps and bounds. Global educational policy as the UN Human Rights declared access and participation of education as a fundamental human right for all global citizens of the world (Odukoya, 2009). In every modern society it is believed that education is the key to national development and there is a need to maintain every level of education especially the preprimary stage, because it is the bedrock upon which all other educational levels build.

The need for enhancing the development process in the developing nations is ever becoming more critical and urgent. The pace at which this can be realized is hinged essentially on the ability of the government to formulate appropriate policies and, very importantly, on the capability of the public bureaucracy to effectively implement the formulated policies. Over the years in Nigeria, numerous brilliant policies have been formulated and implemented. Yet there is no apparent and significant development to show for that as evidenced by the fact that Nigeria has continued to remain in the category of the Least Developed Countries of the world. This suggests that mere formulation of policies should become not the major issue in Nigeria but rather their effective implementation as it is only effectively implemented policies that can bring about national development (Ugwuanyi \& Chukwuemeka, 2013).

The issue of poor policy implementation cannot be overstressed as it has eaten deep into the federation of Nigeria such that Cross River State as a subset is not left out. This downtrend can be seen in the manner in which educational policies at all levels in Cross River State are being administered and implemented. It is the purpose of this seminar paper to explore into various educational policies as contained in the National Policy on Education blueprint, and assess qualitatively the objectives of each educational policy, the proposed implementation strategies, the problems encountered, the situation in Cross River State, and the way forward. This will imply the use of individual observations, as well as a review of already existing literature in order to bring to fore the issues underlying policy implementation in the State. The specific focus of this paper is to assess the implementation strategies of Universal Basic Education (UBE) in Nigeria which constitute part of the foundational aspects of education in Nigeria.

\section{CLARIFICATION OF CONCEPTS}

\subsection{Policy}

Lennon (2009) opined that policy is recognised as a plan or course of action by a government, political party or business designed to influence and determine decisions, actions and other matters. Virtually all aspects of societal enterprise are now the object of policy, a dynamic and valueladen process through which a political system handles a public problem (Plank, Sykes, \& Schneider, 2009; Bolaji, 2014). Thus, a policy may be seen as a written or unwritten guideline that prescribes what is to be done, how it is to be done, where it is to be done, and who is to do it. It can also be added that policies are formulated in both formal and informal institutions, with the difference being in the documentation of such policies and the implementation techniques. 


\subsection{Educational Policy}

Educational policy refers to the collection of laws and rules that govern the operation of an education system (Bolaji, Gray \& Campbell-Evans, 2015). The conceptual clarification of the role of educational policy attests to Nigeria's commitment to policy initiatives for the collective will of citizens, and for the growth and national development of the country. The saying that no nation can rise above its educational development explains educational philosophy of the country which centres on building a free and democratic society; a just and egalitarian society; a united, strong and self-reliant nation; a great and dynamic economy; and a land full of bright opportunities for all citizens (NPE, 2004; 2008; 2013). Therefore, educational policy refers to a set of prescribe rules and a planned course of actions to be taken in order to achieve already stated objectives of an educational programme.

\subsection{Policy Formulation}

Policy formulation refers to the careful and systematic process of developing rules, guidelines and blueprints that must be followed in order to ensure that a programme a achieves its stated aims and objectives. Policies begin as concepts, which are then developed into plans or courses of action that are approved and adopted by governments and communities.

\subsection{Policy implementation}

Policy implementation refers to the systematic process of carefully translating stated policy guidelines and strategies into action. It is the stage that is concern with the actual experimentation, practice, and demonstration of a planned course of action. According to Viennet and Pont(2017), refers to the administration of the laws, guidelines and procedures in which various actors, organization, procedures, and techniques work together to put adopted policies into effect in an effort to attain policy or program goals Therefore, education policy implementation is the purposeful and multidirectional change process aiming to put a specific policy into practice and which may affect an education system on several levels (Viennet \& Pont, 2017).

Education policy implementation is a complex, evolving process that involves many stakeholders and can result in failure if not well targeted. In fact, a range of reasons can prevent implementation from being effective, such as a lack of focus on the implementation processes when defining policies at the system level; a lack of recognition that the core of change processes requires engaging people; and the fact that implementation processes need to be revised to adapt to new complex governance systems. It is therefore crucial to understand it, clarify its determinants and explore ways in which it can be more transparent and effective (Viennet \& Pont, 2017).

\subsection{Realization of goals:}

This is the degree or extent to which the goals formulated for a particular policy or programme are being attained. Goals can be realized satisfactorily or poorly depending on how well the policies formulated were implemented. The process of determining whether goals pertaining to policies are realized, is referred to as policy evaluation. In other words, it through the evaluation process that one can determine the degree to which policy goals are achieved.

\section{UNIVERSAL BASIC EDUCATION POLICY IN NIGERIA}

Universal Basic Education (UBE) is a free, compulsory and 9-year education programme comprising 6 years of primary education and 3 years of junior secondary education. It also includes adult and non-formal education programmes at primary and junior secondary education levels for the adults and out-of-school youths (FRN, 2004). It was designed to be provided by the government and shall be compulsory, free, universal and qualitative. It comprises of 1-year pre-primary, 6 years primary and 3 years of Junior Secondary Education (FRN, 2013).

\subsection{Objectives of Universal Basic Education Policy in Nigeria.}

The followings are the objectives of objectives of UBE according to FRN (2013):

1. developing in the entire citizenry a strong consciousness for education and a strong commitment to its vigorous promotion;

2. the provision of compulsory, free and Universal Basic Education for every Nigerian child of school going age;

3. reducing drastically, the incidence of drop-out from the formal school system, through improved relevance, quality and efficiency;

4. Catering through appropriate forms of complementary approaches to the promotion of basic education, for the learning needs of young persons who for one reason or another, have had to interrupt their schooling; and

5. Ensuring the acquisition of the appropriate levels of literacy, numeracy, communicative and life skills, as well as the ethical, moral, security and civic values needed for laying a solid foundation for life-long learning.

\subsection{Implementation strategies of Universal Basic Education Policy in Nigeria.}

According to FRN (2004), the goals of Universal Basic Education shall be the same as those of primary and junior secondary education. Since UBE combines pre-primary, primary and junior secondary education, the following implementation strategies of UBE were outlined: 
1. UBE shall be tuition free, Universal and compulsory.

2. The following educational services shall be provided: (i) school library; (ii) basic health scheme; (iii) counselling; (iv) educational resource centre; (v) specialist teachers of particular subjects such as Mathematics, Science, Physical Education, etc.

3. Teaching shall be by practical, exploratory and experimental methods.

4. The medium of instruction in the primary school shall be the language of the environment for the first three years. During this period, English shall be taught as a subject.

5. From the fourth year, English shall progressively be used as a medium of instruction and the language of immediate environment and French shall be taught as subjects.

6. For effective teaching and learning, the teacher-pupil ratio shall be $1: 35$;

7. Advancement from one class to another shall be based on continuous assessment;

8. Special efforts shall be made by all appropriate agencies to encourage parents to send their children to school.

9. Government shall therefore provide basic infrastructure and training for the realisation of $\mathrm{UBE}$ goals at the school level.

10. The Primary School Leaving Certificate shall be based only on continuous assessment and shall be issued locally by the head teacher of the school;

11. Everything possible shall be done to discourage the incidence of dropping out at the primary level of education. However, if this occurs, provision shall be made in the context of adult and non-formal education to enable such early leavers to continue with their education

12. Government welcomes the contributions of voluntary agencies, communities and private individuals in the establishment and management of primary schools alongside those provided by the state and local government as long as they meet the minimum standards laid down by the Federal Government.

13. In recognition of the prominent role of Information Communication Technology in advancing knowledge and skills necessary for effective functioning in the modern world, there is urgent need to integrate Information and Communication Technology to education in Nigeria.

14. Students who complete junior secondary school shall be streamed into: (i) the senior secondary school; (ii) the technical college; (iii) an out-of-school vocational training centre; or (iv) an apprenticeship scheme. The streaming shall be based on the result of tests to determine academic ability, aptitude and vocational interest.

\subsection{Critique of the Universal Basic Education policy implementation in Nigeria.}

The critics of the implementation strategies of UBE were directed towards the following areas of the policy implementation strategies.

i. Provision of tuition free, Universal and compulsory education:

It was the aim of UBE to provide free, compulsory and universal education to every Nigerian Child of school going age. The effective implementation of this strategy will have provided opportunity and access for every Nigerian child to be educated. However, this strategy has not been adequately implemented as many parents are being observed paying fees to most junior secondary school students, including registration for the Basic Certificate Examination. The situation is not also different, as many levies are being paid in public primary schools and junior secondary schools by parents and guardians.

Many Nigerian children of school going age are not even in schools which indicate that proper measures are not in use to ensure the universality of the Basic Education. According to Etuk, Ering and Ajake (2012), a good number of Nigerian children are trapped in child labour. As are result of poverty, a number of parents as Oloko (1990) revealed, send their children to either serve as domestic help i.e. house helps/domestic servants or hawkers, just to supplement family income. In addition, it has been observed in Calabar south LGA of Cross River State, where many children of school going age are seen in the streets begging food and items without any opportunity to be in school. These indicate that this section of the policy of UBE has not been adequately implemented.

\section{ii. Provision of educational services:}

The following educational services where identified to be provided as part of the UBE implementation strategy: counselling services, educational resource centre, school library, basic health scheme, specialist teachers in some key subjects. So far, efforts have been made to provide schools with libraries, but without adequate supply of books and other materials.Many public primary and junior secondary schools do not have any professional guidance counsellor. The quality of basic health services rendered in public primary schools have not been observed to be different from the regular national immunization programme which is not part of UBE plans. Many teachers are employed without any educational background, and even the mode of selection is based on politics or connection. In addition to the insufficiencies which have been influential in limiting the potential success of universal basic education, Okiy (2004) revealed that there has also been a poor state of school libraries, among other educational facilities which should have given children the opportunity to be educated 
iii. Practical, exploratory and experimental methods of teaching:

It was specified as part of UBE implementation plans that efforts were going to be made in order to ensure that the quality of teaching provided is practical, exploratory, and experimental. The proper implementation of this strategy will have ensured that learning is made more concrete and real as opposed to the abstract concepts currently thought. It can be said that, this is the most unfortunate policy strategy of the UBE programme because it is in reality, very rare to see any public primary or secondary school teacher delivering lessons with such teaching methods.

Instead, what is common is the traditional method of "talk-chalk" that is widely in used by most primary and junior secondary school teachers. The facilities necessary for experimental and exploratory teaching and learning are missing due to the poor provisions. In addition, Muftahu and Hazri (2015) revealed that many of the teachers were also incompetent and therefore not able to effectively carry out the functions which were anticipated from them. It can therefore, be seen that many teachers even with the few provisions made, are in themselves incompetent in manipulating such devices as computers, tablets and other electronic gadgets. How can one teach what he doesn't know?

\section{$i v$. Use of mother tongue as medium of instruction:}

It is true that the prescription for the use of mother tongue in the teaching and learning process will enable UBE achieve the set goals. This has not been followed up effectively by those implementing the curriculum. Also, the trend of fluent speaking of English Language, as well as the dustbin position given to the mother tongue by most people in Nigeria, has made many parents and teachers to avoid the use of mother tongue in homes and schools respectively. According to Ajayi (2008), another problem associated with teaching in the mother tongue is that there are not sufficient books for children at this level to interact with. The majority of those available are foreign-based and expensive, making them unaffordable and not readily available to these children. The few home-based books that are available are of low quality, making them unappealing and unattractive to read.

\section{v. Teacher-pupil ratio:}

It was stipulated in the implementation guidelines that the teacher-pupil ratio shall be 1:35. Unfortunately, this strategy has not been implemented by the Government. In Cross River State for instance, many pupils in primary schools are assigned to one teacher. The situation is so worse such that some teachers have over 50 pupils which does not give room for effectiveness by the teacher.

\section{vi. Discouraging incidence of school drop-out:}

It was specified as part of the implementation strategies of the UBE programme that, the Government will do everything possible to discourage the incidence of school drop-out rates from the school system. The policy did not prescribe what will be done to discourage the rate of school drop-out from the primary schools. Again, due to the failure of the Government to provide free education to all Nigerian Children of school going age, many pupils whose parents could not meet up with such financial demands from the school system are left with no other option than to disconnect from schools.

\section{vii. Provision of infrastructure:}

The need to provide infrastructures by the Government was clearly stated in the UBE implementation blueprint. The purpose was to ensure that there are adequate classrooms, libraries, buildings, laboratories, and other materials for effective teaching and learning. The effective implementation of this strategy is highly questionable especially given the fact that many primary schools are utilizing buildings that are dilapidated and worn out. In Cross River State, many public secondary and primary schools lack such infrastructures as buildings, adequate classrooms, laboratories, and so on.

Not only in rural schools can this be seen, it is commonplace even in urban areas like Ikom, some parts of Calabar Municipal/south, Ogoja and Obudu.In one study, it was noted that there are infrastructures which were provided to be able to deliver basic education to Nigerians, however, like any other resources, like books and other learning materials, they are insufficient to meet the goals of the program, and to ensure access by everyone (Muftahu \& Hazri, 2015). There is also a shortage of space to accommodate the requirements of the universal basic education. This is basically because the education facilities did not expand in accordance with the growth of the student population. Many of the buildings are already deteriorating, resulting in the creation of learning environments which are not conducive at all (Moja, 2000).

\section{viii. Funding:}

It was stipulated clearly that the Government at all levels will support the UBE scheme with the necessary funds for effective implementation of theprogramme. Unfortunately, the annual budgetary allocations channelled towards education generally, has never met the $26 \%$ benchmark set by UNESCO. In fact, the Education Rights Campaign (ERC) has described the 7.04 per cent allocation to education in the proposed 2018 budget as unacceptable, as it condemned it in strong terms, calling for upward review of budgetary allocation to education to meet the United Nations Education and Scientific Organisation, UNESCO's recommendation of 26\% (Olaniyi, 2017).

It can be inferred from the foregoing that if there are shortfalls in the nation's budget towards education, UBE will also be affected since it is a subset of the education system. This may better explain why many schools in Cross River State and beyond, lack adequate classrooms and other facilities such as computers to encourage hands-on activities in schools. According to Muftahu and Hazri (2015), the yearly 
average allocation for the educational sector in Nigeria has been in a decline. It caused many educational services to be significantly damaged, especially in consideration of the fact that they are provided by the government for free to its citizens.

Another issue in the funding of UBE is the uneven distribution of funds. There is a high rate of unevenness in the funding of UBE programme, with some states or geo-political highly favoured over others. According to statistics in the document obtained from the universal basic education commission, Ebonyi State has not been accessing the UBEC funds since 2009, while Abia, Benue, Cross River, Rivers, Enugu, Kogi, Nasarawa, Ogun and Osun states have failed to access the funds since2011 (Yusha'u, 2014; UBEC, 2014). While only Adamawa, Anambra, Bauchi, Kaduna, Kano, Katsina, Lagos, Sokoto, Taraba and Zamfara states have accessed the 2013 funds, the rest of the 27 states have not accessed theirs and, for 2014, only Sokoto State was able to access its share, the document revealed (Yusha'u,2014; UBEC, 2014).

ix. Collaboration with voluntary agencies, communities and private individuals:

The need for the inclusion of communities and private individuals in the implementation of UBE scheme has to some extent, been beneficial to the programme. This is because many private individuals make donations to the programme, many communities also support the UBE programme by rendering certain services like building some structures, keeping the school environment clean. In Obubra Local Government Area of Cross River State for instance, some communities like Yala, engage in the weekly clearing of the primary school environment as means of supporting the programme. The same community has renovated three collapse buildings. However, due to high rate of corruption on the part of some government officials, some donations made by philanthropist are not used for the purpose for which such donations were made. Some even divert such funds into other projects for personal gains or for the gains of a few government officials.

In some states, private individuals are not even involved in the funding of the program, allowing the education scheme to suffer more setbacks (Eddy \& Akpan, 2009; Jaiyeoba, 2007). It is also assumed that the presence of poor planning and implementation is another thing which has limited the success of this education scheme (Adeyemi, 2007). There are claims which support the assumption that the current funding policies in place, even coupled by private and international donors, are insufficient to be able to support the goals of the program (Muftahu \& Hazri, 2015).

\section{$x$. Integration of ICT to the UBE scheme:}

The National policy of education prescribed there shall be integration of Information and Communication Technologies into the UBE programme. This will have help in raising learners that will be able to function in a dynamic economy, and adapt to the technologically changes of the $21^{\text {st }}$ century. Some efforts have been made in Cross River State to improve the quality of teachers to this end. It is evident that the past government of Sen. Liyel Imoke, and the present administration of Sen. Ben. Ayade have all made efforts to equip teachers with computer systems in order to upgrade them and make them more digital. However, these computers were not offered for free, deductions were made above the market value of such computer systems. Furthermore, in 2013 the computers provided to teachers were sub-standard as opposed to the ones provided in 2018. Due to lack of awareness coupled with greed, and the high deductions made, many teachers sold their computers at a very cheap rate to business people and other private individuals. That is why it is common to see such computers in popular computer business centres instead of classrooms. Despite these efforts, there was no evidence in terms of the supply of ICT equipment to all the schools for effective teaching and learning. Few secondary schools in Cross River State were supplied with ICT equipment like UPS, computer sets, and printers, without any corresponding source of electricity.

According to Adeosun (2010), one of the things which have contributed to the lack of efficiency of the education system in the country is the insufficient integration of information and communication technology. Factors such as poor internet connectivity, poor knowledge and technical skills in information and communication technology infrastructures, lack of time, lack of financial requirements, and reluctance from both the teachers and the learners have all been highly influential in the failure to integrate such technology in education.

\subsection{Realization of Universal Basic Education policy objectives}

In assessing the realization of UBE goals and objectives, it will be pertinent to ask five critical questions:

i. Are the entire citizens of the country conscious towards education with a strong commitment towards its vigorous promotion?

ii. Is the education provided at either pre-primary, primary or junior secondary school levels compulsory? Is it totally free? Is every Nigerian child of school going age in school?

iii. Are there still school drop-outs from the formal school system in Nigeria?

iv. Are young people who for one reason or another interrupted their schooling, given any complimentary education or opportunity for better livelihood?

v. Are there appropriate levels of literacy, numeracy, communicative and life skills in young learners within the formal school system? In other words, can every child in primary or junior secondary school read, write, speak simple correct English, or solve basic mathematics problems involving arithmetic? Do all these young leaners possess one or more vocational skills? Are there still ethical, moral, 
security, and civic issues within the primary and secondary school systems?

If for any reason, there is a "yes" to any one, two or more questions posed above, it implies that the goals of UBE in Nigeria have not been realized. The degree of realization of such objectives depends on the number of "Yes" or "No" provided as answers to the questions posed above. The higher the number of "Yes", the higher the degree of UBE goals realization, and vice versa.

\section{RECOMMENDATIONS FOR EFFECTIVE MANAGEMENT OF THE UNIVERSAL BASIC EDUCATION PROGRAMME IN NIGERIA.}

Based on the issues raised with respect to the implementation of UBE programme in Nigeria, as well as the realization of set objectives, the following recommendations were made.

i. Efforts should be made by the three tiers of Government to make education completely free at the primary and junior secondary school levels in order to encourage universal access to the education provided.

ii. Regulatory bodies such as Universal Basic Education Commission at the federal or State Universal Education Board at the state level, should ensure that proper measures are taken to bring to book any parent or guardian withholding their children from going to school.

iii. Educational services such as library, counselling, and health services should be adequately provided to all public schools in order to ensure that learners educational, career, and health needs are adequately catered for.

iv. There should be a total shift in paradigm from the traditional methods of teaching to a more practical, experimental, and exploratory teaching that will encourage hands-on activities. This can be achieved through close monitoring and supervision of teachers while in the classroom, and the provision of facilities.

v. Use of mother tongue should be encourage especially at the early stages of children educational development in order to enable them understand English Language effectively.

vi. Given the high rate of population in Nigerian Schools, and the need to make learning more practical, the teacher-pupil ratio should be set at 1:5 (One teacher to five pupils) at the pre-primary section; 1:20 (One teacher to twenty pupils) at the primary section; and 1:35 (one teacher to thirty-five students) at the junior secondary school section.

vii. There should be adequate provision and supply of infrastructure to schools; while worn out facilities/structures should be fixed or replaced in order to avoid inadequacies in terms of infrastructural provisions.

viii. Funds should be adequately allocated to education from the nation's budget, at least to the tune of the $26 \%$ benchmark set by UNESCO. Funds from private individuals and other donors should be used judiciously for intended purposes, and for public benefit.

ix. Private individuals and other donors should continue supporting education with funds and other materials considered appropriate to ensure the smooth running of the school.

x. ICT should be integrated into the formal school system by making provisions for the creation and supply of ICT equipment and experts to schools. Teachers should also be trained on the use of such equipment. There should also be constant supply of electric power to sustain such equipment provided.

\section{CONCLUSION}

It is a fact that the UBE policy just like every other policy of Education contained in the National Policy on Education were well drafted and clearly stated. If such policies are followed appropriately as stated, the Nigerian Education Sphere will witness a dramatic rise in terms of quality, and in the attainment of the Nation's objectives. The education sector has witnessed a lot of problems especially, in the implementation phase of all educational policies. So far, efforts are still being made by the Government and other stakeholders to improve the quality of education in Nigeria. In doing this there is need for such efforts to be made with virtues such as equity, trust, reliability and rationality. With this in place, the Nigerian Educational system will move the next level.

\section{REFERENCES}

[1]. Adeosun, O. (2010). Quality basic education development in Nigeria: Imperative use of ICT. Journal of International Cooperation in Education, 13(2), 193 - 211.

[2]. Adeyemi, T.O. (2007). Teacher preparation and availability for achieving Basic Education in Ondo State, Nigeria. Humanity and Social Sciences Journal, 2(2), 159 - 168.

[3]. Ajayi, H. O. (2008). Early childhood education in Nigeria: a reality or a mirage? Contemporary Issues in Early Childhood, 9(4), $375-380$.

[4]. Bolaji, S. D; Gray J. R. \& Campbell-Evans G. (2015). Why do policies fail in Nigeria? Journal of Education \& Social Policy, 2(5), $57-66$.

[5]. Bolaji, S. D. (2014). Intent to action: overcoming the barriers to universal basic education policy implementation in Nigeria. A doctoral thesis submitted to the graduate research school of Edith Cowan University, Western Australia.

[6]. Eddy, E. N; \& Akpan, M. E. (2009). The prospect of UBE program in Akwa Ibom State, South-South Nigeria. International NGO Journal, 4(2), 46 - 49.

[7]. Etuk, G. R; Ering, S. O. \& Ajake, U. E. (2012). Nigeria's universal basic education (UBE.) policy: A sociological analysis. American International Journal of Contemporary Research; 2(7), $179-183$.

[8]. Federal Republic of Nigeria (2004). National policy on education $\left(4^{\text {th }} E d\right.$.). Abuja: NERDC Publishers 
[9]. Federal Republic of Nigeria (2008). National policy on education $\left(5^{\text {th }} E d\right.$.). Abuja: NERDC Publishers

[10]. Federal Republic of Nigeria (2013). National policy on education $\left(6^{\text {th }} E d\right.$.). Abuja: NERDC Publishers.

[11]. Jaiyeoba, A. O. (2007). Perceived impact of universal basic education on national development in Nigeria. International Journal of African and African-American Studies, 6(1), $48-58$.

[12]. Lennon, S. (2009). Educational policy. Retrieved on $13^{\text {th }}$ Aug. from http://www.lennonportal. net/index file/policy

[13]. Moja, T. (2010). Nigeria education sector analysis: An analytical synthesis of performance and main issues. New York: New York University.

[14]. Muftahu J. S. \& Hazri, J. (2015). Policy of universal basic education in Nigeria: An examination of its effectiveness on implementation and management. American International Journal of Contemporary Research; 5(6), 147 -155.

[15]. Odukoya, D. (2009). Formulation and implementation of educational policies in Nigeria. Educational Research Network for West and Central Africa (ERNCAWA). Retrieved on November 2, 2015. Available at http://www.slideshare.net/ernwaca/formulation-andimplementation-of educational-policies-in-nigeria
[16]. Okiy, R. B. (2004). The universal basic education (UBE) programme and the development of school libraries in Nigeria: A catalyst for greater female participation in national development. Information Development, 20(1), 43 - 50.

[17]. Olaniyi A. (2017). 2018 budget: 7.04 per cent allocation to education unacceptable - ERC tells FG. Retrieved on $23^{\text {rd }}$ Aug. 2018 from http://dailypost.ng/2017/11/23/2018-budget-7-04-percent-allocation-education-unacceptable-erc-tells-fg/

[18]. Oloko, B. A. (1990). Evolution for prevention of child labour and for working children (28-31). International Child Labour Seminar. Amsterdam.

[19]. Plank, D. N; Sykes, G. \& Schneider, B. (2009). Handbook on educational policy research. Hoboken, N. J: Routledge.

[20]. Ugwuanyi, B. I. \& Chukwuemeka, E. O. (2013). The obstacles to effective policy implementation by the public bureaucracy in developing nations: the case of Nigeria. Kuwait Chapter of Arabian Journal of Business and Management Review; 2(7), 59 68.

[21]. Viennet, R. \& Pont, B. (2017). Education policy implementation: A literature review and proposed framework. OECD Education Working Paper No. 162. 